\title{
Declaration of the Javan hawk eagle Spizaetus bartelsi as Indonesia's National Rare Animal impedes conservation of the species
}

\author{
VinCENT NiJMAN, CHRis R. Shepherd and S. VAN BALEN
}

\begin{abstract}
The Endangered Javan hawk eagle Spizaetus bartelsi is threatened in part by the illegal pet trade. In 1993 the species was declared Indonesia's National Rare/ Precious Animal, by former President Soeharto. Trade in the species and keeping it as a pet are illegal. We consolidated data about the species in trade, as observed at bird markets, with private owners, in zoological gardens (to date the species has not been bred in captivity and those in zoos are all wild-caught that were formerly in trade) and wildlife rescue centres, involving at least 68 birds. The average price for the species at bird markets was USD $40(n=5)$. The number observed at bird markets appears to have increased over time. Furthermore, prior to its declaration as a National Rare/Precious Animal it was not considered in trade to be different from other large eagles. There are indications that individuals have been illegally exported to other parts of Asia. In the early 1990s no Javan hawk eagles were kept in zoos but it became in demand in the mid 1990s and now there are 11 in six zoos throughout Java. Law enforcement with respect to trade in eagles appears to be largely absent but nine Javan hawk eagles have been brought to a wildlife rescue centre on Java. Overall, the data suggest there was an increase in trade in Javan hawk eagles after it was declared the National Rare/Precious Animal. When a threatened species is put in the spotlight to highlight its conservation plight, this should be done with close cooperation between conservation NGOs and government organizations, with appropriate legislation and/or management plans to prevent overexploitation.
\end{abstract}

Keywords CITES, conservation, Javan hawk eagle, Indonesia, Spizaetus bartelsi, wildlife trade, zoos.

\section{Introduction}

O ne of the best-known regulatory policy instruments for international wildlife trade is the Convention on International Trade in Endangered Species of Wild Fauna

VINCENT NIJMAN* (Corresponding author), CHRIS R. SHEPHERD ${ }^{\dagger}$ and S. VAN BALEN Zoological Museum, University of Amsterdam, PO Box 94766, 1090 GT Amsterdam, The Netherlands. E-mail vnijman@brookes.ac.uk

*Also at: Oxford Brookes University, School of Social Sciences and Law, Oxford, UK.

${ }^{\dagger}$ Also at: TRAFFIC South-east Asia, Taman SEA, Petaling Jaya, Selangor, Malaysia.

Received 19 June 2007. Revision requested 26 July 2007.

Accepted 30 October 2007. and Flora (CITES). With the aim of preventing species becoming economically or ecologically extinct, thousands of species have been put on one of the three CITES Appendices, precluding or regulating commercial trade. Once appropriate laws are passed by a contracting Party to CITES, police, customs inspectors, wildlife officials, and other government officers are empowered to enforce CITES regulations. Rivalan et al. (2007) demonstrated that last-minute bans (such as CITES-listing) lead to significant declines in wildlife trade volumes after implementation but that in the transitional period between announcement of the ban and its implementation, legal trade volumes increase significantly. Thus, drawing attention to the threatened status of a species, and regulating its trade, may lead to an increase in trade. Likewise, Stuart et al. (2006) showed that the mere description of a species as new may lead to an unwanted increase in trade to such an extent that this may lead to the extinction of the species. Recently, Cooney \& Jepson (2006) opened the debate on the effectiveness of wildlife trade regulatory policy instruments, in particular when it refers to indiscriminate import bans on birds, and this led to a series of comments (Burton, 2006; Gilardi, 2006; Jepson \& Cooney, 2006; Rabinovich, 2006; Roe, 2006) highlighting that regulatory policy instruments themselves may lead to an increase in trade and thus jeopardize the conservation status of the traded species.

Here we show that increased attention to the threatened Javan hawk eagle Spizaetus bartelsi, by declaring it a National Rare/Precious Animal, introduced it to the public and increased demand for it in trade. We also provide an overview of all aspects of trade in Javan hawk eagles and make recommendations to curb the trade.

\section{Status of the Javan hawk eagle}

The Javan hawk eagle S. bartelsi is confined to the last remnants of rainforest on the densely populated island of Java, Indonesia (Collar et al., 2001). Like most endemic birds on Java, the Javan hawk eagle is an evergreen forest specialist. As with the forest it lives in, populations of Javan hawk eagles are severely fragmented and possibly isolated from each other (van Balen et al., 1999a, 2001). The population has been estimated at c. 1,000 individuals, c. 50\% of which comprises adult pairs (van Balen et al., 2001). Because of this small population size and significant decline in numbers, the species is categorized as Endangered on the IUCN Red List (Collar et al., 2001; IUCN, 2007). 
Always described as being rare (Kuroda, 1936; Brown \& Amadon, 1968), until recently the species was one of the world's least known raptors (Meyburg, 1986). On 10 January 1993 the Javan hawk eagle was declared Indonesia's National Rare/Precious Animal (Satwa Langka Nasional; the Indonesian word langka originates from the Javanese language, and can be translated as 'rare' or 'precious' but also as 'expensive' and 'unheard of'; Prawiroatmojo, 1985) by then President Soeharto (Widyastuti, 1993), and immediately the bird became well-known to the general public. The rationale behind the declaration was that increased attention would lead to better protection of this rare bird. Javan hawk eagles were depicted on banners and stamps, on the cover of telephone directories, and became in great demand from zoos and malevolent collectors (Sözer et al., 1998). In the socio-political context of the Javanese desire to keep birds as pets, with rare and expensive birds offering a means to display one's social status, the declaration of the Javan hawk eagle as a National Precious Animal may have led to an increase in demand. Simultaneously, the species' rise to fame made it the focal point for a number of conservation related projects (Røv et al., 1997; van Balen et al., 1999, 2000, 2001; Setiadi et al., 2000) and currently the Javan hawk eagle is arguably the best-studied bird in Indonesia (Meyburg et al., 1989; van Balen \& Meyburg, 1994; Nijman \& van Balen, 2003; Gjershaug et al., 2004; Kaneda et al., 2007).

All diurnal birds of prey are protected by Indonesian law (No 421/Kpts/Um/8/8/1970), and rare and endangered species receive extra protection under article 21(2) of the Act R.I. No. 5 of 1990; fines and subsequent imprisonment can be imposed on law breakers. Despite being legally protected, eagles are commonly offered for sale in many bird markets (Shepherd et al., 2004; V. Nijman, C.R. Shepherd \& S. van Balen, unpubl. data). Javan hawk eagles are included in Appendix II of CITES, regulating international commercial trade in the species. Trade has been identified as one of the major threats to the survival of populations of Javan hawk eagles (Sözer et al., 1998; Collar et al., 2001), although there are little relevant data available. In the ASEAN Regional Action Plan on Trade in Wild Fauna and Flora 2005-2010, it was recognized that there is a need to promote research and monitoring of CITESrelated issues by exchanging information on, amongst other matters, regional market dynamics and trade flows to improve understanding of producer-consumer relations in the region. Trade in birds in Indonesia has a high economic value (Nash, 1993; Jepson \& Ladle, 2005) and, as such, there is an increasing need to understand the drivers behind illegal bird trade in Asia. Not only is this paramount for understanding which approaches for reduction of unsustainable wildlife harvest and trade function, and which do not, but also to make better informed decisions regarding trade regulations and conservation interventions.

\section{Data acquisition}

Over the last 2 decades $\mathrm{SvB}$ and $\mathrm{VN}$ have studied the biology of Javan hawk eagles and conducted island-wide surveys (van Balen et al., 1999a,b; Nijman et al., 2000; Nijman 2004a,b), whilst over this period CRS has collected data on wildlife trade in Indonesia (Shepherd et al., 2004). Collectively we have accumulated data on the trade in Javan hawk eagles, some first hand but often from secondary sources. Wherever possible we tried to verify these latter records, e.g. by visiting the locality ourselves or, based on descriptions or photographs, by checking whether or not the bird was actually a Javan hawk eagle. Sometimes, however, we had to rely on the expertise and reliability of the observer. We obtained data from four sources: bird and animal markets, zoos and bird parks, wildlife rescue centres, and the available literature. We number zoos and bird parks so as not to disclose their identity. We were interested in trade in Javan hawk eagles only, and therefore we explicitly dismissed all references to trade in eagles in general, although these may have included an unknown number of Javan hawk eagles. We have surveyed bird markets and zoos throughout western Indonesia; the focus here is on Java, although where relevant data from other parts of Indonesia, and from abroad, are included.

From the early 1990s onwards TRAFFIC has frequently conducted surveys of Javan bird markets. We checked the TRAFFIC archive for records of Javan hawk eagles. In the period 1979-1997 (SvB) and 1994-2006 (VN \& CSR) we conducted informal surveys of 35 bird markets (in 22 cities) on Java, and of these 15 were surveyed $\geq 10$ times over 3 or more years. At most markets eagles, and other protected wildlife, are sold in particular sections (i.e. at the back, or in adjacent alleyways) and particular attention was paid to these areas. Additional data from Javan hawk eagles sold at bird markets were collected from the Indonesian language literature (newspaper clippings, unpublished market survey reports, and students' theses), and by making requests to other researchers who may have data on trade in the species.

SvB and colleagues (Suwelo et al., 1991) made an inventory of the number of eagles in eight zoos on Java. VN conducted a survey of six (1994) and nine (2003) zoos in Java and Bali, tallying all eagles that were on display as well as those that were kept at breeding facilities and/or quarantine facilities. In 1994 and 1995 VN regularly visited the two zoos that at that time displayed Javan hawk eagles and recorded the minimal turnover of the species. In addition, we obtained information from zoo staff and the literature on additional birds on display.

Starting in 2002 five wildlife rescue centres have been established on Java. In 2003 these were visited by VN, and the number of Javan hawk eagles present were tallied. Data on the origin of these, and potentially previously present 
Javan hawk eagles were requested. These data were updated in 2006 by making enquiries to these centres.

\section{Results}

\section{Bird markets}

An overview of all known cases of Javan hawk eagles in trade, i.e. all that we were able to locate, is summarized in Table 1. Prior to 1993 few Javan hawk eagles were observed in trade. Over 1979-1993 82 spot checks in seven towns yielded no sighting of Javan hawk eagles (S. van Balen, unpubl. data). Basuni \& Setiyani (1989) and van Helvoort (1981), surveying markets in Jakarta in 1989 and in Bandung in 1977-1978, respectively, did not encounter Javan hawk eagles. S. Nash, working for TRAFFIC, observed a few individuals during extensive market surveys in the early 1990s. We came across two records in the 1980s, involving three birds, from Pramuka bird market in Jakarta, and one from 1975 near Meru Betiri in East Java.

Following declaration as Indonesia's National Rare Animal more Javan hawk eagles were observed in trade, and from a number of surveys conducted during the mid and late 1990 it appears that 1-2 were occasionally observed for sale. In November 1999 a single Javan hawk eagle was for sale in Mataram, on the island of Lombok, c. $100 \mathrm{~km}$ east of Java. After 2000, Javan hawk eagles were regularly observed on markets. In the first 6 months of 2004 P. H. Hoyois observed c. 20 for sale at markets in towns on Java. Allegedly, in March 2004, 10 birds were sent to South Korea from Jakarta in west Java, and later that year another 11 were sent to either Singapore or Taiwan from Surabaya in East Java (P.H. Hoyois, pers. comm. to VN, 2004). Five quotes of asking prices are known to us that, converted to

TABLE 1 Overview of Javan hawk eagles Spizaetus bartelsi in trade, in zoological parks, and in wildlife rescue centres.

\begin{tabular}{|c|c|c|c|c|c|c|}
\hline Year & No. & Age & Purpose & Venue & Locality $^{4}$ & Source \\
\hline 1975 & 1 & Adult & Sale & Private collection & Meru Betiri, EJ & H. Bartels, pers. comm., 1994 \\
\hline 1985 & 1 & & Sale & Market & Pramuka Jakarta, WJ & P. Andrew in Thiollay \& Meyburg, 1988 \\
\hline 1989 & 2 & Adult & Sale & Market & Pramuka Jakarta, WJ & A. van den Berg in van Balen et al., 1999 \\
\hline 1991 & 1 & Juvenile & Display & Zoo & Zoo $1, \mathrm{WJ}$ & S. van Balen, pers. comm., 1994 \\
\hline 1992 & 1 & Juvenile & & Private collection & & Femina Magazine \\
\hline c. $1991-93$ & $>2$ & & Sale & Market & Pramuka Jakarta, WJ & S. Nash, in litt., 2007 \\
\hline c. 1993 & 1 & Adult & Sale & Market & Jakarta, WJ & M. Riffel in Thiollay, 1994 \\
\hline 1994 & 2 & Juvenile & Sale & Market & Bojonggaleng, WJ & Sözer \& Nijman, 1995 \\
\hline 1994 & $10^{1}$ & Ad./juv. & Display & Zoo & Zoo $1-3$, WJ, EJ & Sözer \& Nijman, 1995 \\
\hline 1995 & $15^{2}$ & Ad./juv. & Display & Zoo & $\begin{array}{l}\text { Zoo 1-2, WJ, } \\
\text { Birdpark 1, WJ }\end{array}$ & Jepson, 1995 \\
\hline 1996 & 8 & & Display & Zoo & Zoo $1-2$, WJ & Manansang et al., 1996 \\
\hline 1996 & 1 & & Sale & Market & Bratang Surabaya, EJ & Nursaid \& Astuti, 1996 \\
\hline 1996 & 1 & & Sale & Market & Pramuka Jakarta, WJ & Nursaid \& Astuti, 1996 \\
\hline 1996 & 1 & & Sale & Market & Malang, EJ & Nursaid \& Astuti, 1996 \\
\hline 1997 & 1 & Adult & Sale & Market & WJ & Hapsoro, pers. comm., 1997 \\
\hline 1998 & 1 & & Sale & Market & Pramuka Jakarta, WJ & V. Nijman, pers. obs. \\
\hline 1998 & 1 & Immature & Sale & Market & Bandung, WJ & Z. Rakhman, pers. comm., 2003 \\
\hline 1999 & 1 & & Sale & Market & Mataram, Lombok & C. Trainor, pers. comm., 1999 \\
\hline 1999 & 1 & & Sale & Market & Pramuka Jakarta, WJ & CITES Tiger Mission Technical Team, 1999 \\
\hline 2000 & 1 & & Display & Private collection & $\begin{array}{l}\text { Biak F\&RCC, } \\
\text { New Guinea }\end{array}$ & Anonymous, 2000 \\
\hline 2001 & 1 & & Sale & Market & Bandung Plaza, WJ & YPAL, pers. comm., 2003 \\
\hline 2001 & 1 & Juvenile & & Rescue centre & Cikananga, WJ & R. Sözer, in litt., 2006 \\
\hline 2003 & 11 & & Display & Zoo & Zoo $1-6, \mathrm{WJ}, \mathrm{CJ}, \mathrm{EJ}$ & V. Nijman, pers. obs. \\
\hline 2003 & 1 & Juvenile & & Rescue centre & Cikananga, WJ & R. Sözer, in litt., 2006 \\
\hline 2004 & $5^{3}$ & Juv./imm. & & Rescue centre & Cikananga, WJ & R. Sözer, in litt., 2006 \\
\hline 2004 & 1 & Adult & Sale & Market & Bandung Indah Plaza, WJ & Z. Rakhman, pers. comm., 2004 \\
\hline 2004 & 20 & & Sale & Market & Jakarta/Bandung, WJ & P.H. Hoyois, pers. comm., 2004 \\
\hline 2004 & 6 & & Display & Private collection & $\begin{array}{l}\text { Biak F\&RCC, } \\
\text { New Guinea }\end{array}$ & P.H. Hoyois, pers. comm., 2004 \\
\hline 2006 & 1 & & & Rescue centre & Cikananga, WJ & R. Sözer, in litt., 2006 \\
\hline
\end{tabular}

${ }^{1}$ Five of which died

${ }^{2}$ Eight of which died

${ }^{3}$ One of which was euthanized

${ }^{4} \mathrm{CJ}$, province of Central Java (including Yogyakarta); EJ, province of East Java; WJ, province of West Java (including Jakarta) 
the exchange rate at the time, average c. USD 40, range from USD 4 at the place of capture to USD 60 at Pramuka market in Jakarta.

These data suggest that a substantial number of Javan hawk eagles have been observed in trade within the last 2 decades. Because data were often collected in an ad hoc manner, and surveys that yielded data on Javan hawk eagles were more likely to become known to us than those that yielded no data, it is difficult to estimate total numbers. Those surveys that can be quantified are as follows: JulyOctober 1996, surveys in nine towns located three individuals, one at each of three markets (Nursaid \& Astuti, 1996); October 2001-March 2002, surveys of markets in seven towns yielded no observations of Javan hawk eagles (Atmoto, 2002); October-November 2004, surveys in Bandung located one Javan hawk eagle (Z. Rakhman, pers. comm.); surveys by TRAFFIC in August-October 2003 in seven towns yielded no data on Javan hawk eagles.

\section{Zoological gardens and private institutions}

In 1991 no Javan hawk eagles were present amongst any of the 215 eagles in eight zoos and bird parks surveyed (Suwelo et al., 1991). Later, in 1991 or in 1992, the first Javan hawk eagle was displayed at Zoo 1 in west Java. In the beginning of 1994 Zoo 2, also in west Java, obtained its first Javan hawk eagle, and by the end of the year there were four birds on display. In 1995 and 1996 both zoos had a combined total of eight birds on display, with at least an additional six birds having died. In 1995 one was present for a short period in Zoo 3 in East Java but this one also died. Zoos were eager to obtain Javan hawk eagles, and gradually the number of Javan hawk eagles in zoos, and the number of zoos that had the species on display grew. In 2003 there was a total of 11 Javan hawk eagles on display in six zoos. Although records of birds that died are not kept, or are not public, based on information provided by zoo staff, our own observations, and deductions based on the age of the birds on display (a 1st year juvenile observed in 1995 cannot be the same as an 2nd year immature observed in 1994, for example), at least 21 birds were involved.

In 1996 a captive-breeding programme was initiated by a consortium of Indonesian zoos. Sexing of captive Javan hawk eagles by laparoscopy was deemed a priority by international zoo biologists (Manansang et al., 1996), the execution of which resulted in a high mortality rate (Collar et al., 2001). As of 2006 the captive-breeding programme had not produced any offspring. According to the zoos, the Javan hawk eagles in their care are the result of either confiscations by the forestry department or were received as donations by anonymous private owners (in 1995 it was understood that by Indonesian law zoos and bird parks were not allowed actively to obtain new specimens but could receive donations from anonymous private owners; Jepson, 1995), and thus all originate from the illegal wildlife trade.
Between December 1999 and April 2000 the Biak Falconry and Raptor Conservation Center, a private enterprise in Irian Jaya on the island of New Guinea, obtained one Javan hawk eagle (in addition to another 17 hawk eagles belonging to five species). Although the centre only had permits to house raptors from Irian Jaya, in 2000 its target was to obtain an additional four Javan hawk eagles (Anon., 2000). In, or prior to, 2004 this was achieved, as in that year six Javan hawk eagles were present (P.H. Hoyois, 2004, pers. comm. to $\mathrm{VN}$ ).

\section{Wildlife rescue centres}

In 2001 the Cikananga Wildlife Rescue Centre received its first Javan hawk eagle. At the beginning of 2006, nine birds were received, one of which was euthanized, one transferred to Zoo 4, and two released in the wild. All were 1st or 2nd year birds, and arrived at the centre through the regional nature conservation agency, one as the result of a confiscation and eight as donations.

\section{Discussion}

Increasingly it is becoming clear that wildlife trade in Asia is a huge business affecting thousands of threatened taxa worldwide (Nash, 1993; Shepherd et al., 2004; Nekaris \& Jaffe, 2007; Nijman \& Shepherd, 2007) and market surveys have demonstrated the ineffectiveness of enforcement of wildlife trade regulations (Shepherd \& Nijman, 2008). We have documented c. 70 Javan hawk eagles in trade (including specimens appearing in zoos) in the last 2 decades (Fig. 1). Most of these were on Java, seven (in two places) in

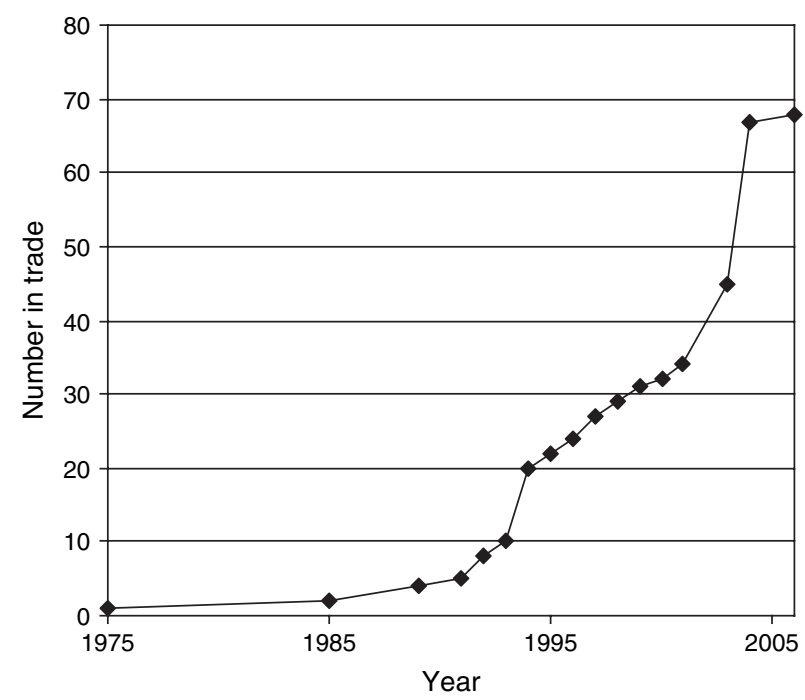

Fig. 1 Cumulative number of Javan hawk eagles Spizaetus bartelsi in trade (as observed at bird markets, zoos and rescue centres) from 1975 to 2006, suggesting an increase in numbers after the species was declared National Rare/Precious Animal in 1993. 
other parts of Indonesia, and there were indications that a substantial number were sent to other parts of Asia. Pressure is exerted by embassy staff from certain countries who buy eagles at local bird markets and hold them at their housing compounds, out of reach of officers of the Indonesian Nature Conservation Department because of their diplomatic immunity (D.S. Hadi, 1993, pers. comm. to SvB). We suspect that this also involves Javan hawk eagles but we have no data to substantiate this.

Pramuka bird market in Jakarta and, to a lesser extent, Pasar Bandung Indah Plaza in Bandung, both in West Java, are where Javan hawk eagles are most frequently offered for sale. Pramuka, in particular, is well-known for its trade in rare and legally protected wildlife from Java, the rest of Indonesia, and abroad (Nash, 1993; Nijman, 2005). Monitoring of wildlife trade, especially in the 1980s and 1990s, was more frequent in Jakarta and other parts of West Java, so whether or not the less frequent recording of Javan hawk eagles at some of the larger bird markets in Central Java (Yogjakarta, Semarang) or East Java (Surabaya, Malang) is a true reflection of their availability remains unknown.

Increasingly, more birds are seen in zoos and bird parks, the record of which with respect to Javan hawk eagles is poor, with high levels of mortality, as also noted by Collar et al. (2001). Javan hawk eagles arriving at the rescue centres are often in poor condition (R. Sözer, pers. comm., 2006). It was difficult to obtain data on the origin of Javan hawk eagles in zoos as zoo staff were reluctant to provide the relevant information (cf. Nijman, 2006). When the origin was given it referred mostly to 'anonymous private owners'. Combined with specimens in the wildlife rescue centres and the Biak Falconry and Raptor Conservation Center, over 20 Javan hawk eagles are now in captivity.

We were able to age 35 Javan hawk eagles observed in trade or upon arrival in zoos or rescue centres: two thirds were either 1st or 2nd year juveniles, and one third were older birds. Bearing in mind that there is a time-lag between the time of capture and the time the individual is first observed in a market or a zoo, this suggests that most of the Javan hawk eagles in trade are captured when still young, either by robbing the nest or by catching juvenile birds (cf. Nijman et al., 2000; Nijman \& van Balen, 2003).

We found it difficult to obtain data on Javan hawk eagles in trade. Apart from our own research we located a number of statements relating to the species, often referring to apparent observations of single birds only (Thiollay \& Meyburg, 1988; Meyburg et al., 1989). Grier (1996) claimed '20 [are] known in captivity (including eight in two zoos, and eight at Jakarta bird markets), plus others [i.e. four] in private hands', whereas Manansang et al. (1996) stated 'there is one in a private collection and an estimated 10 at local bird markets'. We do not know what the sources are for these data but we infer they are educated guesses at best. Some authors do provide a source for the quantities of Javan hawk eagles observed in trade but these data are not incontrovertible. Mooney (1997) stated that 'Surveys consistently show that 30-40 [Javan hawk eagles] are openly offered for sale in the bird markets in Java each year' referring to Nursaid et al. (1996). Nursaid et al. (1996) did mention the figure of $30-40$ but this referred to all species of eagle they observed, not just Javan hawk eagles, and they did not survey over a year or multiple year periods. Nursaid et al. (1996) and Nursaid \& Astuti (1996) did record three (possibly four) Javan hawk eagles at three markets during 36 visits to 12 markets over a 4 -month period.

The number of records of Javan hawk eagles at markets increased over time (Table 1). It is difficult to assess whether or not there has been a genuine increase in the trade of the species but when enquiring about Javan hawk eagles specifically at bird markets from the 1980 s to the mid 1990s, few dealers considered Javan hawk eagles different from any other large eagle. In later years, however, Javan hawk eagles were sold as 'Javan hawk eagles, Indonesia's national bird'. The appearance of Javan hawk eagles at distant markets such as those in Mataram, the explicit expression of interest by the Biak Falconry and Raptor Conservation Center, as well as several zoos, in obtaining Javan hawk eagles, suggest that not only the latter institutions but also others have created an interest in the species.

Whether or not the Javan hawk eagles that appeared in zoos and bird parks after the species was declared Indonesia's National Rare/Precious Animal were already in the illegal possession of private owners or traders, or whether the expression of interest by zoos and bird fanciers created a larger demand, and hence an increase in captures, is unknown. If the latter supposition is correct, the declaration of the Javan hawk eagle as Indonesia's National Rare/Precious Animal may have actually jeopardized the conservation of the species. In this the case of the Javan hawk eagle has parallels with that of newly described species that immediately become in high demand and with species that, merely because of their protected status, are in more demand than unprotected species.

We make a number of specific recommendations to help curb trade in Javan hawk eagles: (1) allow only a small number of authorized zoos and/or bird parks to display a restricted number of individuals, (2) require all captive birds to be marked with microchips and registered with the national authorities, (3) regularly monitor bird markets by rotating teams involving the forestry department, police and local NGOs (operating in mixed teams to prevent internal collusion), (4) confiscate any eagles offered for sale and prosecute dealers, and (5) educate the public through the media that it is illegal and inappropriate to buy or keep protected species as pets.

When a threatened species is put in the spotlight to highlight its conservation plight this should ideally be done in close 
cooperation with government organizations so as to coordinate this action with legislation and/or management plans that thwart overexploitation (cf Stuart et al., 2006). If it is the government itself that brings the species into the spotlight, as was the case with the Javan hawk eagle, we urge them to remain vigilant and apply the same cautionary principle.

\section{Acknowledgements}

The study was conducted under sponsorship of the Indonesian Institute of Sciences (LIPI), and the Directorate General for Forest Protection and Conservation (PHKA), and is part of the Word Bank funded Economic and Social Drivers of the Wildlife Trade in South-east Asia project (contract number 7136248 to TRAFFIC), and it supports the objective of the ASEAN-Wildlife Enforcement Network, which aims to eliminate illegal international wildlife trade in South-east Asia. For data and support we thank Hapsoro, Dr Phillipe H. Hoyois, Dr Paul Jepson, Stephen Nash, Pupung Firman Narwatha, Rosek Nursaid, Dr Dewi M. Prawiradilaga, Zeni Rakhman, Andi Prima Setiadi, Iwan Setiawan and Resit Sözer. Three reviewers provided helpful suggestions.

\section{References}

A dмојо. (2002) Perdagangan satwa liar dilundungi. Pantau, Bogor, Indonesia.

Anon. (2000) Progress Report of the Biak Falconry and Raptor Conservation Center. Yayasan Peduli Lestari, Biak, Indonesia.

B Alen, S. van. (1996) Javan Hawk-eagle Spizaetus bartelsi. PHPA/ BirdLife International-Indonesia Programme Threatened Species Assessment Series No. 1. PHKA/BirdLife International, Bogor, Indonesia.

Balen, S. van \& Meyburg, B.-U. (1994) The Java hawk eagle Spizaetus bartelsi: results of recent research on distribution, status and ecology. In Raptors in the Modern World (eds B.-U. Meyburg \& R.D. Chancellor), pp. 89-92. WWGBP, Berlin, Germany.

Balen, S. van, Nijman, V. \& Prins, H.H.T. (2000) The Javan hawk-eagle: misconceptions about rareness and threat. Biological Conservation, 96, 297-304.

Balen, S. van, Nijman, V. \& Sözer, R. (1999) Distribution and conservation of the Javan hawk-eagle Spizaetus bartelsi. Bird Conservation International, 9, 333-349.

Balen, S. van, Nijman, V. \& Sözer, R. (2001) Conservation of the endemic Javan hawk-eagle Spizaetus bartelsi Stresemann, 1924 (Aves: Falconiformes): density, age-structure and population numbers. Contributions to Zoology, 70, 161-173.

Balen, S. van, Sözer, R., Nijman, V., Meijaard, E., Dennis, R. \& JEPSON, P. (1999) Juvenile plumage of Javan crested honey buzzard, with comments on mimicry in south-eastern Asian Pernis and Spizaetus. Dutch Birding, 21, 192-198.

Basuni, S. \& Setiyani, G. (1989) Studi perdagangan burung di pasar Pramuka, Jakarta dan teknik penangkapan burung di alam. Media Konservasi, 2, 9-18.

Brown, L. \& Amadon, D. (1968) Eagles, Hawks and Falcons of the World, 2 Vols. Country Life Books, Feltham, UK.
BURTON, J.A. (2006) The international wild bird trade: a response to Cooney \& Jepson. Oryx, 40, 261.

Cites Tiger Mission Technical Team (1999). Issues Relating to CITES Species. Tiger. Technical Mission Report to the 42nd Meeting of the CITES Standing Committee, Lisbon, Portugal, 28 Sept to 1 Oct 1999. Doc.SC.42.10.4. Http://www.cites.org/eng/com/sc/42/42-10-4.pdf [accessed 9 October 2008].

Collar, N.J., Andreev, J.V., Chan, S., Crosby, M.J., Subramany a, S. \& Tовіаs, J.A. (eds.) (2001) Threatened Birds of Asia: The BirdLife International Red Data Book. BirdLife International, Cambridge, UK.

Cooney, R. \& Jepson, P. (2006) The international wild bird trade: what's wrong with blanket bans? Oryx, 40, 18-23.

Gilardi, J.D. (2006) Captured for conservation: will cages save wild birds? A response to Cooney \& Jepson. Oryx, 40, 24-26.

Gjershaug, J.O., Rov, N., Nygard, T., Prawiradilaga, D.M., Afianto, M.Y., Hapsoro \& Supriatna, A. (2004) Homerange size of the Javan hawk-eagle (Spizaetus bartelsi) estimated from direct observations and radio-telemetry. Journal of Raptor Research, 38, 343-349.

Grier, J.W. (1996) Comments. In Population and Habitat Viability Assessment for the Javan Hawk-eagle (Spizaetus bartelsi) (eds J. Manansang, P. Miller, J.W. Grier \& U.S. Seal), pp. 47-51. Conservation Breeding Specialist Group, Apple Valley, USA.

Helvoort, B. van. (1981) Bird Populations in the Rural Ecosystems of West Java. Nature Conservation Department Publication no. 560. Agricultural University, Wageningen, The Netherlands.

IUCN (2007) 2007 IUCN Red List of Threatened Species. IUCN, Gland, Switzerland. Http://www.iucnredlist.org/ [accessed 20 June 2008].

Jepson, P. (1995) BirdLife International Indonesia Programme Memorandum 2/3/5c, 18 July 1995. Unpublished Memorandum, BirdLife International, Bogor, Indonesia.

JePSON, P. \& CoONEy, R. (2006) International conservation needs flexibility in wildlife trade policy: a reply to Burton. Oryx, 40, 262-263.

JEPSON, P. \& LADLE, R.J. (2005) Bird-keeping in Indonesia: conservation impacts and the potential for substitution-based conservation responses. Oryx, 39, 442-448.

Kaneda, H., Prawiradilaga, D.M. \& Yamagishi, S. (2007) Home range and habitat use of an individual of the Javan hawkeagle Spizaetus bartelsi. Journal of Raptor Research, 41, 68-71.

Kunoda, N. (1936) Birds of the Island of Java. Privately published, Tokyo, Japan.

Manansang, J., Miller, P., Grier, J.W. \& Seal, U.S. (eds) (1996) Population and Habitat Viability Assessment for the Javan Hawkeagle (Spizaetus bartelsi). Conservation Breeding Specialist Group, Apple Valley, USA.

Meyburg, B.-U. (1986) Threatened and near-threatened diurnal birds of prey of the world. Birds of Prey Bulletin, 3, 1-12.

Meyburg, B.-U., van Balen, S., Thiollay, J.-M. \& Chancellor, R.D. (1989) Observations on the endangered Java hawk eagle Spizaetus bartelsi. In Raptors in the Modern World (eds B.-U. Meyburg \& R.D. Chancellor), pp. 279-299. WWGBP, Berlin, Germany.

Mooney, N. (1997) Status and Conservation of Elang Jawa (The Javan Hawk Eagle Spizaetus bartelsi). Environment Australia, Hobart, Australia.

NAsH, S.V. (1993) Sold for a Song-The Trade in South-east Asian Non-CITES birds. TRAFFIC South-east Asia, Kuala Lumpur, Malaysia.

NeKaris, K.A.I. \& JafFe, S. (2007) Unexpected diversity in slow loris (Nycticebus spp.) within the Javan pet trade: implications for slow loris taxonomy. Contributions to Zoology, 76, 196-206. 
Nijman, V. (2004a) Habitat segregation in two congeneric hawkeagles (Spizaetus bartelsi and S. cirrhatus) in Java, Indonesia. Journal of Tropical Ecology, 20, 105-111.

NiJman, V. (2004b) Seasonal variation in naturally occurring mobbing behaviour of drongos (Dicruridae) towards two avian predators. Ethology, Ecology and Evolution, 16, 25-32.

Nijman, V. (2005) In Full Swing. An Assessment of the Trade in Gibbons and Orang-utans on Java and Bali, Indonesia. TRAFFIC South-east Asia, Kuala Lumpur, Malaysia.

Nijman, V. (2006) In-situ and ex-situ status of the Javan gibbon, and the role of zoos in conservation of the species. Contributions to Zoology, 76, 161-168.

NiJMAN, V. \& VAN BALEN, S. (2003) Wandering stars: age-related habitat use and dispersal of Javan hawk-eagles (Spizaetus bartelsi). Journal für Ornithologie, 144, 451-458.

Nijman, V., van Balen, S. \& Sözer, R. (2000) Breeding biology of Javan hawk-eagle Spizaetus bartelsi in West Java, Indonesia. Emu, $100,125-132$.

Nijman, V. \& Shepherd, C.R. (2007) Trade in non-native, CITESlisted, wildlife in Asia, as exemplified by the trade in freshwater turtles and tortoises (Chelonidae) in Thailand. Contributions to Zoology, 76, 207-212.

Nursaid, R. \& Astuti, M. (1996) Survey perdagangan burung di pasar Malang (januari-juli 1996). KSBK, Malang, Indonesia.

Nursaid, R., Qomariana, Y., Kurniawan, I. \& Chandra, R. (1996) Endangered Species Trade in Java and Bali, An Investigation Report. KSBK, Malang, Indonesia.

Prawiroatmojo, S. (1985) Bausastra Jawa-Indonesia, Vol. 1. Gunung Agung, Jakarta, Indonesia.

Rabinovich, J. (2006) To ban or not to ban, seeking the middle path: a response to Gilardi. Oryx, 40, 263-264.

Rivalen, P., Delmas, V., Angulo, E., Bull, L.S., Hall, R.J., Courchamp, F. et al. (2007) Can bans stimulate wildlife trade? Nature 447, 529-530.

Roe, D. (2006) Blanket bans-conservation or imperialism? A response to Cooney \& Jepson. Oryx, 40, 27-28.

Røv, N., Gjershaug, J.O., Prawiradilaga, D.M., Hapsoro \& Su priatna, A.A. (1997) Conservation Biology of the Javan Hawkeagle. Progress report prepared for the Indonesian Institute of Sciences (LIPI) and the Ministry of State for Environment (LH), Bogor, Indonesia.

Setiadi, A.P., Rakhman, Z., Nurwatha, P.F., Muchtar, M. \& Raharjaningtrah, W. (200o) Distribusi, populasi, ekologi dan konservasi Elang Jawa Spizaetus bartelsi Stresemann 1924 di Jawa Barat bagian selatan. BP/FFI/BirdLife International/YPAL-HIMBIO UNPAD, Bandung, Indonesia.
Shepherd, C.R. \& Nijman, V. (2008) Trade in bear parts from Myanmar: an illustration of the ineffectiveness of enforcement of international wildlife trade regulations. Biodiversity and Conservation, 17, 35-42.

Shepherd, C.R., Sukumaran, J. \& Wich, S.A. (2004) Open Season: An Analysis of the Pet Trade in Medan, Sumatra 1997-2001. TRAFFIC South-east Asia, Kuala Lumpur, Malaysia.

SÖZER, R. \& NiJMAN, V. (1995) Behavioural ecology, distribution and conservation of the Javan hawk-eagle Spizaetus bartelsi Stresemann, 1924. Verslagen \& Technische Gegevens, 62, $1-122$.

Sözer, R., Nijman, V., Setiaman, I., van Balen, S., Prawiradilaga, D.M. \& Subijanto, J. (1998) Pemulihan Jenis Elang Jawa/Javan Hawk-eagle Recovery Plan. KMNLH/PHPA/LIPI/ BirdLife International-Indonesia Programme, Bogor, Indonesia.

Stuart, B.L., Rhodin, A.G.J., Grismer, L.L. \& Hansel, T. (2006) Scientific description can imperil species. Science, 312, 1137.

Sumelo, I.S., Kuncoro, D.M., Marlon, R., Prodjoatmodjo, S. \& VAN BALEN, S. (1991) Penelitian pelestarian burung bondol, elang bondol, Haliastur indus, di kawasan DKI Jakarta. Mitra Satwa PKBSI, Jakarta, Indonesia.

Thiollay, J.-M. (1994) Family Accipitridae (hawks and eagles). In Handbook of Birds of the World, Vol. 2: New World Vultures to Guineafowl (eds J. del Hoyo, A. Elliott \& J. Sargatal), pp. 52-105. Lynx Edicions, Barcelona, Spain.

Thiollay, J.-M. \& Meyburg, B.-U. (1988) Forest fragmentation and the conservation of raptors: a survey on the island of Java. Biological Conservation, 44, 229-250.

Widyastuti, Y.E. (1993) Flora-fauna maskot nasional dan propinsi. Penebar Swadaya, Jakarta, Indonesia.

\section{Biographical sketches}

VinCENT Nijman studies the effects of human-induced disturbances on vertebrate populations in Asia, with a strong emphasis on assessing the impacts of illegal wildlife trade. He is also a member of the Dutch CITES Scientific Authority. Chris R. ShePherd is with TRAFFIC South-east Asia, and has been monitoring wildlife trade throughout the region for the past 15 years. His current research focuses on assessing the effectiveness of CITES as a conservation tool. B AS VAN BALEN is a freelance ornithologist working in Indonesia for the last 3 decades. Apart from studying the effects of forest fragmentation on birds in Java and Bali, he has worked in 29 of the 33 provinces in Indonesia and is currently involved in assessments of High Conservation Value Forests in Borneo. 